\title{
O TWÓRCZOŚCI KRZYSZTOFA FRYSZTACKIEGO
}

\section{Abstract \\ On the output of Krzysztof Frysztacki}

Krzysztof Frysztacki is one of the most influential Polish authors in the fields of social work, urban sociology and social policy. His scientific activity has lasted almost half a century. He is the author or co-author of twelve books and nearly two hundred scientific articles. In the article I describe his creative writing and research work. My main focus is on his last books published in 2019. I present his achievements and contribution to Polish social work education and applied sociology in the context of social changes taking place at the Jagiellonian University and in Poland over the last fifty years.

Key words: Polish social work, urban sociology, Jagiellonian University, history

Artykuł ten ma charakter okolicznościowy, związany z ponad półwieczną działalnością naukową Krzysztofa Frysztackiego. Utrzymany jest w nieco innej konwencji niż typowe teksty socjologiczne, gdyż bardziej nawiązuje do literatury pięknej. Uważam, że prace Krzysztofa Frysztackiego zasługują na takie ujęcie, ponieważ cechują je szczególnie piękna polszczyzna i sposób prezentacji tematu. Zazwyczaj typowe podsumowania dorobku uznanych socjologów mają inny, bardziej scjentystyczny charakter. Ich autorzy najczęściej wskazują na osiągnięte wyniki, zastosowaną aparaturę naukową, udział w grantach i projektach badaczy, którzy odnieśli sukces w nauce i zasługują na upamiętnienie.

Aby lepiej ukazać twórczość Krzysztofa Frysztackiego, posłużę się przenośnią botaniczną i opiszę ją, odwołując się do stadiów tworzenia się rośliny, począwszy od ziarna, poprzez kwiat, aż do owocu. Jego praca twórcza trwa od ponad pięćdziesięciu lat, w bardzo konkurencyjnym środowisku, w którym trwa walka o przetrwanie i sukces, gdzie istnieje ciągłe ryzyko marginalizacji lub likwidacji ze strony zwolenników innych metod badawczych, poddyscyplin, kierunków kształcenia, mód, polityki naukowej i publicznego aktywizmu. Ekspansja i szybki wzrost specjalistycznych nisz jest możliwa tylko w szczególnych momentach, a mimo to bohaterowi tej opowieści udało się przetrwać w tych wymagających i nieprzyjaznych warunkach. Co więcej, udało mu się odnieść trwały sukces w postaci instytucjonalizacji specjalności i kierunku pracy socjalnej i założenia jedynego czasopisma wydawanego przez Instytut Socjologii przez ponad ćwierć wieku. 


\section{Ziarno}

Z zewnątrz trudno określić, czym jest ten zalążek, swoiste ziarno czyjejś twórczej działalności. Czym jest ta niematerialna - w przeciwieństwie do botanicznej - materia, która rozwija się w człowieku i wytwarza całą roślinę, czy to jest kłos pszenicy czy kilkutonowy dąb. Na podstawie wypowiedzi Krzysztofa Frysztackiego w rozmowach z współpracownikami wydaje się, że takim ziarnem była reakcja na kryzys polityczny i społeczny w kraju wiosną 1968 roku, który doprowadził do zmiany młodzieńczych decyzji życiowych, porzuceniu studiów na Politechnice Śląskiej i przystąpieniu do egzaminów na socjologię na Uniwersytecie Jagiellońskim, a następnie podjęcie tychże studiów.

Absolwent Politechniki Śląskiej w latach 60. XX wieku mógł oczekiwać bardzo dobrego wynagrodzenia i szybkiego awansu na szczeblach drabiny zawodowej. Decyzja o zmianie rodzaju studiów ze ścisłych na humanistyczne, z kierunku o długiej tradycji na nowo powstałą socjologię, już po pierwszym roku, była zatem obarczona dużym ryzykiem. Zmiany w kraju, walka polityczna, która w okresie państwowego socjalizmu była niewidoczna dla opinii publicznej, groźba załamania porządku społeczno-politycznego i nadzieja na zastąpienie gomułkowskiej „małej stabilizacji” czymś nowym i nieznanym, dały jednak impuls do przemyśleń i skłoniły go do kształcenia się w nowym kierunku, a następnie profesjonalnego rozwoju na polu nauk społecznych.

Ziarno padło na grunt przygotowany przez poprzedników. Należy wspomnieć szczególnie o Janie Szczepańskim i jego książce Elementarne pojęcia socjologii, która w owym okresie była dostępna w księgarniach. Jan Szczepański stawał się człowiekiem instytucją w ówczesnej Polsce, a jego kariera rozkwitła w latach 70. XX wieku. Na jego nagrobku na cmentarzu w Ustroniu jest napis „socjolog humanista” i to określnie trafnie oddaje jego życie i spuściznę, jaką po sobie pozostawił. Socjologia miała być nauką zachodnią, opozycyjną wobec rzeczywistości państwowego socjalizmu oraz formą humanizmu, świeckiego rozumienia i działania w świecie. Socjologia humanistyczna, czy socjologia ze współczynnikiem humanistycznym, wydawała się pozytywną odpowiedzią na życie w państwowym socjalizmie z jego gospodarką niedoboru dóbr konsumpcyjnych i autorytarną władzą jednej partii. Elementarne pojęcia socjologii były jedną z pierwszych lektur młodego Krzysztofa, który przyswoił sobie ją jeszcze przed egzaminami na studia i zajęciami dydaktycznymi, w trakcie których książka Szczepańskiego była jedną z podstawowych lektur.

\section{Korzeń}

Tworzenie korzenia z ziarna to prawdziwa „czarna robota”, która musi doprowadzić do wytworzenia struktury biologicznej wielokrotnie przewyższającej ziarno powierzchnią i rozmiarami. Z ziaren o wielkości około centymetra powstaje biologicznie czynny układ o wielu metrach, czasami nawet kilometrach długości i objętości przekraczającej wielkość ziarna setki tysięcy razy. 
Takim korzeniem w twórczości naukowej i pisarskiej były studia i lata asystentury w Instytucie Socjologii Uniwersytetu Jagiellońskiego. Krzysztof Frysztacki rozpoczą studia jako jeden z pierwszych roczników studentów socjologii. W latach uprzednich studia socjologiczne były możliwe jedynie jako drugi kierunek, pierwszym mogła być filozofia, polonistyka czy inne filologie. Instytut Socjologii powstał w 1970 roku w wyniku fuzji dwóch katedr: etnografii ogólnej i socjologii oraz socjologii i demografii, istniejących od 1957 roku. Kierownikami tych katedr byli profesorowie Kazimierz Dobrowolski i Paweł Rybicki.

Początek lat 70. XX wieku przyniósł zmiany polityczne i społeczne, podobne do tych z 1957 roku. Władze stały się bardziej liberalne, nastąpiło otwarcie na Zachód, zaczęły się ukazywać przekłady współczesnej zachodniej literatury pięknej i naukowej, mimo że często miały charakter wydawnictw o ograniczonym zasięgu lub dostępnych jedynie wybranym studentom i pracownikom w bibliotekach.

Były to zatem warunki bardzo sprzyjające rozwojowi intelektualnemu i emocjonalnemu młodego człowieka. Zainteresowania badawcze Krzysztofa Frysztackiego rozwijały się stopniowo w stronę miasta jako środowiska społecznego i kulturowego, a jego patronem został profesor Paweł Rybicki, który poświęcił miastu oraz miejskości znaczną część swojej działalności naukowej i napisał obszerną monografię Społeczeństwo miejskie (wydaną w 1972 roku).

Struktura społeczna w latach 70. XX wieku wyglądała zgoła odmiennie niż współcześnie. Większość ludności żyła na wsi i w miasteczkach, istniało wiele małych gospodarstw rolnych, które były przedmiotem narodowej dumy jako obszar obroniony przed radzieckim modelem kolektywizacji i upaństwowienia własności rolnej. W dużych miastach mieszkało mniej ludzi niż na terenach wiejskich i nie były one siedliskiem „klasy kreatywnej”, jak to ma miejsce obecnie. Znaczna część wysiłku badawczego socjologów była skierowana na tereny wiejskie i stanowiła próby dowiedzenia się jak żyją i co myślą chłopi oraz ich rodziny. Socjologia miasta była relatywnie mniej rozbudowana niż socjologia wsi. Powstawały książki i opracowania na temat nowo powstałych miast, takich jak Nowa Huta czy Nowe Tychy, a ich autorami byli młodzi socjologowie, którzy właśnie ukończyli studia, na przykład Tomasz Goban-Klas, Jacek Wódz, Maria Halamska, Renata Siemieńska czy Jerzy Sulimski.

Owym korzeniem twórczości Frysztackiego były studia w nowo utworzonym Instytucie Socjologii i lata asystentury. Działo się to pod kierunkiem profesorów starszego pokolenia, którzy zdobyli wiedzę przed II wojną światową na uniwersytetach niemieckich, austriackich czy francuskich. Do wymienionych wcześniej Kazimierza Dobrowolskiego i Pawła Rybickiego należy dodać nazwisko Andrzeja Waligórskiego, który był uczniem Bronisława Malinowskiego w Londynie i przed śmiercią przez kilka lat pracował w Instytucie Socjologii. Młody student czerpał zatem soki i substancje odżywcze z gleby bogatej w zachodnioeuropejskie dziedzictwo socjologii formalnej i strukturalno-funkcjonalnej (durkheimowskiej i brytyjskich wariantów antropologii kulturowej).

Socjologia krakowska w tym okresie pozostawała w tyle za starszymi i silniejszymi personalnie ośrodkami w Warszawie (Stefan Nowak, Jerzy i Barbara Szaccy) czy Łodzi 
(Jan i Krystyna Lutyńscy, Zygmunt Gostkowski). Wkrótce miało się to jednak zmienić, ponieważ pracownikami Instytutu zostali Hieronim Kubiak i Piotr Sztompka, a jego dyrektorem - Władysław Kwaśniewicz, socjolog o niezwykłym potencjale grupotwórczym i wspólnotowym. Silnymi stronami powstającego instytutu były: entuzjazm pracowników tworzących nowe miejsce na mapie krajowej socjologii, doświadczenie starych profesorów i otwarte ścieżki kariery dla ludzi młodych. Sprzyjały mu również zmiany ustrojowe oraz między innymi częściowe otwarcie na Zachód, bardziej swobodne postawy czołowych marksistów i katolickich intelektualistów oraz nadzieja na niezależność polityczną i gospodarczą.

Rozwój intelektualny młodego studenta, a następnie pracownika można zatem metaforycznie przedstawić jako wykształcenie i wzrost korzenia. Czerpał on siłę z kontaktów i rozmów z wymienionymi wyżej postaciami, ożywienia socjologii krajowej (nawiązanie relacji z przedstawicielami uniwersytetów zachodnioeuropejskich i amerykańskich) oraz pojawienia się czołowych socjologów światowych w Polsce i Krakowie. Na tym etapie korzeń ciągle znajdował się jednak pod ziemią, gdzie nie miał bezpośredniego kontaktu ze światłem słonecznym, narażony był za to na podgryzanie i ataki grzybów, insektów, toksycznych składników gleby i szeroko pojętego środowiska.

\section{Łodyga}

Po wydostaniu się z ziemi korzeń zmienia się w łodygę, którą w tej biograficznej metaforze będą doktorat i habilitacja. Po ukończeniu studiów utrwaliły się jego zainteresowania badawcze, czyli miasto i jego mieszkańcy ze szczególnym uwzględnieniem Krakowa. Praca magisterska napisana pod opieką Pawła Rybickiego dotyczyła polskiej socjologii miasta (1973). Rozprawa doktorska napisana pod kierunkiem Władysława Kwaśniewicza była studium wybranych grup mieszkańców Krakowa (1977).

W pierwszych latach pracy w Instytucie Socjologii, Krzysztof Frysztacki kontynuował sposób analizy zagadnień miejskich charakterystyczny dla lat 70. XX wieku, czyli poszukiwał wyjaśnienia procesów miastotwórczych w klasycznej socjologii amerykańskiej. Jednym z głównych pionierów badań nad miastem był Louis Wirth, członek chicagowskiej szkoły socjologicznej, jeden z czołowych socjologów miasta na wczesnym etapie rozwoju dyscypliny. Krzysztof Frysztacki przetłumaczył z języka angielskiego jedną z jego rozpraw. Niestety, nie doszło do publikacji całości polskiego tłumaczenia, ponieważ zgubił on maszynopis podczas jednej z przeprowadzek.

Habilitacja była oparta właśnie na badaniach miasta amerykańskiego, a dokładniej Polonii amerykańskiej w typowym mieście emigracyjnym, czyli Buffalo. Uzyskanie habilitacji stanowi w świecie akademickim moment ważnego przejścia: z niesamodzielności w samodzielność, dlatego właśnie zakończenie rozrostu łodygi traktuję symbolicznie jako uzyskanie niezależności naukowej i możliwość tworzenia nowych biologicznych struktur, które będą dostarczać łodydze i korzeniom produktów fotosyntezy. 


\section{Liść i kwiat}

Treść i tematyka prac Krzysztofa Frysztackiego jest zróżnicowana, lecz wewnętrznie spójna i tworzy swoisty czworobok obejmujący swoim wierzchołkiem społeczeństwo miejskie (szczególnie Krakowa oraz Buffalo), historię pomocy społecznej i pracy socjalnej, problemy społeczne oraz politykę społeczną. Bardzo popularna okazała się książka, napisana wspólnie z Januszem Pragłowskim, o dziejach filantropii i pomocy społecznej, pokazująca rozwój tej problematyki w USA, Wielkiej Brytanii, ale również w Polsce. Krzysztof Frysztacki opracował pierwszą w Polsce monografię dotyczącą socjologii problemów społecznych. W innych książkach, których był współautorem, zajmował się głównie ubóstwem i bezdomnymi dziećmi. Logiczne powiązanie między kwestiami socjalnymi a polityką społeczną doprowadziło do napisania studiów poświęconych amerykańskiemu państwu opiekuńczemu (welfare state) oraz polityce społecznej w Europie i w Polsce. Wiele z tych publikacji powstało w twórczej współpracy z Krzysztofem Piątkiem z Uniwersytetu Mikołaja Kopernika.

Styl pisarstwa Krzysztofa Frysztackiego jest niepowtarzalny i bardzo trudny do podrobienia. Jest czymś, co odróżnia go od rzeszy współczesnych socjologów i czyni jego twórczość wyjątkową. Teksty socjologiczne bardzo często mają techniczny charakter, a ich autorzy posługują się standardowym słownictwem i składnią. W przypadku Frysztackiego mamy do czynienia ze stylem łatwo rozpoznawalnym: pełnym zdań podrzędnych, wielokrotnie złożonych, wtrąceń, komentarzy prezentujących subiektywne oceny oraz swoistej retoryczności tekstów. Używa on - co obecnie jest raczej niespotykane w literaturze przedmiotu - pierwszej osoby liczby mnogiej, a nie liczby pojedynczej. Przez ten zabieg czytelnik ma wrażenie wspólnego myślenia i snucia refleksji. Często stawia pytania co do słuszności poglądów omawianych autorów i stara się na nie odpowiedzieć. Nie stosuje typowych zdań rozstrzygających, lecz raczej pogłębia możliwe warianty odpowiedzi i mnoży wątpliwości, ze sceptycyzmem podchodząc do poszczególnych spraw. Czytelnik dostaje zatem „gęsty opis” danego zagadnienia ze wszystkimi możliwymi uwagami, komentarzami, odnośnikami i skojarzeniami. Jest to twórczość pisarska rzadka obecnie - $\mathrm{w}$ dobie sformalizowanych i skąpych wypowiedzi autorów publikacji socjologicznych, którzy ukrywają swoje wyobrażenia, nastawienia i poglądy. Pozwala ona na niuansowanie zagadnień, precyzyjne i wielostronne ich przedstawianie, prowadzenie dialogu z autorami wcześniejszych prac i opatrywania wcześniej napisanego tekstu ciągłymi komentarzami odautorskimi. Zasługą autora są również próby spolszczania lub wprowadzania nowych polskich nazw jako odpowiedników angielskiej terminologii. W ten sposób Frysztacki wychodzi naprzeciw powszechnemu trendowi w socjologii i pracy socjalnej polegającemu na używaniu angielskich terminów i posługiwania się nimi bez podawania znaczenia w języku polskim lub używania rodzimej terminologii. Co więcej, często tworzy on nowe określenia i zwroty lub przywraca je do użycia, na przykład pisząc o „społeczno-socjalnej” (odpowiedzialności), „,iedlisku” czy "problemacie” itp. Praktyka ta powoduje, że tekst nabiera niepowtarzalnego charakteru, staje się wyjątkowy i pozwala rozpoznać unikatowego autora. Jednocześnie zastosowane 
słownictwo, zwroty i pojęcia dają efekt elegancji i mocnego zakorzenienia w tradycji socjologii krakowskiej.

W ostatnich latach pracy na Uniwersytecie Jagiellońskim Frysztacki wydał dwie ważne książki. Pierwsza z nich to podręcznik akademicki Praca socjalna. 30 wykładów, który ukazał się nakładem Wydawnictwa Naukowego PWN w Warszawie w 2019 roku. Przykładem jego sukcesów w dziedzinie nauk społecznych mogą być prace, takie jak Resocjalizacja pod redakcją Bronisława Urbana i Jana M. Stanika, Pedagogika społeczna pod redakcją Ewy Marynowicz-Hetki, Polityka społeczna pod redakcją Grażyny Firlit-Fesnak i Małgorzaty Szylko-Skoczny, a następnie Polityka społeczna. Nowe wydanie pod redakcją Grażyny Firlit-Fesnak i Jacka Męciny. Polska praca socjalna nie doczekała się tak wszechstronnego i głębokiego kompendium do 2019 roku, co było oczywistym brakiem. Warto wspomnieć, że w krajach sąsiednich od wielu lat ukazują się podobne publikacje. Wymienię w tym miejscu: Encyklopedię pracy socjalnej Oldřicha Matouška, która jest używana w dydaktyce nie tylko w Czechach, lecz także Słowacji, Handbuch. Sociale Arbeit pod redakcją Hansa-Uwe Otto i Hansa Thiersche oraz amerykańską, aktualizowaną na bieżąco i wydawaną co trzy-cztery lata Social Workers' Desk Reference pod redakcją Alberta R. Robertsa.

Opracowanie takiego podręcznika miało zatem charakter pionierski. Jego powstanie doprowadziło zarazem do zmniejszenia zapóźnienia między Polską a krajami o dłuższej tradycji, bogatszej edukacji i praktyce pracy socjalnej. Praca socjalna. 30 wykładów jest pewną formą uprawomocnienia pracy socjalnej jako młodej dyscypliny akademickiej, która uzyskała autonomię na poziomie studiów magisterskich mniej niż dziesięć lat temu. Warto nadmienić, że redaktor tomu uzyskał zgodę na publikację tekstów najbardziej doświadczonych i uznanych autorów z najbardziej renomowanych uniwersytetów w Polsce, w części należącej do kategorii uniwersytetów badawczych (Uniwersytet Jagielloński, Uniwersytet Warszawski, Uniwersytet Mikołaja Kopernika, Uniwersytet im. Adama Mickiewicza). Do tej pory polscy studenci mogli korzystać z wartościowych opracowań, lecz były one tłumaczeniami z literatury zagranicznej, zazwyczaj anglosaskiej pracy socjalnej (autorstwa Chrisa Becketta, Carole Sutton, Davida Howe’a, Mel Gray i Stephena A. Webba). Realia ustrojowe, dziedzictwo pokoleń i kształt instytucji w krajach takich, jak USA czy Wielka Brytania są jednak zasadniczo różne od polskich czy środkowoeuropejskich, dlatego pozycja jako pierwszy polski akademicki podręcznik pracy socjalnej ma niebagatelne znaczenie dla rozwoju całej dziedziny.

Należy spodziewać się, że w ciągu najbliższych kilku lat, a może dziesięcioleci, podręcznik pracy socjalnej pod redakcją Krzysztofa Frysztackiego pełnić będzie taką samą funkcję, jak niegdyś Elementarne pojęcia socjologii Jana Szczepańskiego czy Metody badań socjologicznych Stefana Nowaka na wczesnym etapie rozwoju socjologii akademickiej.

Kolejna książka autora, Wokót pracy socjalnej. Od koncepcji teorii do kontekstów empiryczno-aplikacyjnych, ukazała się w 2019 roku nakładem Wydawnictwa Uniwersytetu Jagiellońskiego. Składa się z dziewięciu rozdziałów. Pierwszy z nich omawia najbardziej wpływowe teorie socjologiczne, które bezpośrednio wpłynęły na pracę socjalną - przede wszystkim Charlesa Lemerta. Wykorzystuje również wczesny dorobek Piotra Sztompki, 
który wiele uwagi poświęcił metodologii i roli teorii w wyjaśnianiu zjawisk społecznych oraz późniejszy - głównie poświęcone zaufaniu społecznemu i jego roli w tworzeniu dobrego społeczeństwa.

Praca socjalna jest dziedziną heterogeniczną, która uwzględnia wiedzę z wielu dziedzin między innymi socjologii, psychologii, psychiatrii, pedagogiki społecznej i prawa. Autor podkreśla korzyści płynące ze styku tych różnych dyscyplin i wzajemne przenikanie się wątków. Posługuje się tu przykładami zaczerpniętymi zarówno z prac autorów amerykańskich, jak i polskich. Wskazuje również, za Demetriusem Iatridisem, na kwestię sprawiedliwości dystrybucyjnej. Co istotne, jest to wątek zazwyczaj przemilczany i nieobecny w polskich książkach na temat pracy socjalnej. Tymczasem polityka społeczna kierująca się zasadą sprawiedliwości dystrybucyjnej jest nieusuwalnym składnikiem działań zmierzających do realizacji wartości pracy socjalnej.

W twórczości Frysztackiego wielką rolę odgrywa teoria socjologiczna, w szczególności odwołania do prac przedstawicieli szkoły funkcjonalnej - Émile’a Durkheima i Roberta Mertona. To podkreślanie związku pomiędzy koncepcjami klasyków socjologii i współczesną praktyką pracy socjalnej jest częste i trwałe. Wydaje się, że nacisk na teorię społeczną, głownie teorię socjologiczną, jest jedną z oznak myślenia autora, który do wyjaśniania i zrozumienia bieżących wydarzeń i procesów społecznych systematycznie powoływał się na myśli i idee ojców założycieli socjologii. To podejście łączyło się z krytyką polskiej pedagogiki jako dyscypliny aspirującej do włączenia pracy socjalnej w swoje ramy. Zdaniem autora pedagogika nie wypracowała naukowych założeń ani twierdzeń, które dawałyby szansę na rozwój pracy socjalnej jako działalności praktycznej spełniającej wymogi praktyki opartej na dowodach naukowych (evidence based practice).

Autor omawia koncepcje problemów społecznych jako twardego zaplecza intelektualnego dla pracy socjalnej. Jest to popularne i utrwalone podejście w amerykańskiej pracy socjalnej oraz w polskiej polityce społecznej. Przedstawienie głównych perspektyw poznawczych w badaniach problemów społecznych przychodzi mu z tym większą łatwością, że od wielu lat śledził nowe książki na ten temat, które ukazywały się w Stanach Zjednoczonych. Co więcej, sam napisał podstawową monografię na ten temat Socjologia problemów społecznych, która ukazała się w 2009 roku w serii „Wykłady z Socjologii” redagowanej przez Piotra Sztompkę, obok monografii autorstwa Krzysztofa Gorlacha, Edmunda Wnuka-Lipińskiego, Bohdana Jałowieckiego czy Marka S. Szczepańskiego.

Układem odniesienia dla Krzysztofa Frysztackiego w sferze kształcenia polskiej pracy socjalnej była edukacja i działalność pracowników socjalnych w Stanach Zjednoczonych. Podejście to jest uzasadnione najdłuższą tradycją w kształceniu uniwersyteckim oraz autonomią tej dyscypliny naukowej, uznanej przez całe środowisko akademickie w USA, przejawiająca się między innymi nadawaniem stopnia doktora na amerykańskich uniwersytetach.

Praca socjalna w takim ujęciu jest częścią międzynarodowej aktywności naukowców i ma - podobnie jak socjologia - kosmopolityczny charakter. Między innymi z tego powodu Frysztacki zamieścił w Socjalnej Ameryce fragment tekstu H. Wayne’a Johnsona, w którym stwierdza on, że „socjologia ma się do pracy socjalnej mniej więcej tak, 
jak biologia ma się do medycyny" (Johnson 1995: 13). Tenże autor wskazał również na różnicę między socjologią i pracą socjalną: „socjolog poświęca się poszukiwaniu prawdy, a pracownik socjalny funkcjonuje innej podstawie wartości, a mianowicie odzwierciedlającej dziedzictwo judeochrześcijańskie oraz humanitarne i demokratyczne wpływy Ameryki i świata zachodniego" (Johnson 1995: 13).

Za szczególnie wartościowe w Socjalnej Ameryce uznaję rozdziały poświęcone pomocy społecznej jako swoistej instytucji państwa amerykańskiego. Wiedza autora jest unikalna, ponieważ miał on okazję nie tylko poznać ją od strony książkowej, lecz również na bieżąco śledzić zmiany i reformy amerykańskiego systemu opieki społecznej (welfare), w tym - najgłośniejszej - reformy Billa Clintona. W książce znajdujemy omówienia prac czołowych znawców zagadnienia, takich jak Andrew W. Dobelstein, June Axinn czy Herman Levin. W tej pozycji autor nie faworyzuje czyjegoś punktu widzenia, nie preferuje orędowników konserwatywnego czy liberalnego modelu polityki społecznej, lecz przedstawia pogłębione studium tych opinii, opatrzone przyjaznym komentarzem.

Trudno się dziwić, że miejskie problemy społeczne i praca socjalna znajdują się w centrum uwagi autora. Przekonująco przedstawia on szkołę chicagowską i jej kontynuatorów oraz Hull House Jane Addams i początki pracy socjalnej w wielkim mieście. Porusza również tematy planowania miejskiego i sprawiedliwości społecznej. Są one bardzo ważne w kontekście realizowanej w wielu polskich metropoliach polityki intensywnej zabudowy miejskiej i uprzywilejowania deweloperów; co więcej, pokazują alternatywne modele rozwoju społeczeństwa miejskiego. Problemy społeczne, polityka miejska i praca socjalna spotykają się w jednym miejscu i ukazują użyteczność tych kategorii pojęciowych oraz socjologii stosowanej opartej na modelu zapoczątkowanej przez Jane Addams i rozwijanej przez jej następców. Istotne wydają się również refleksje Krzysztofa Frysztackiego nad miejscem uprawiania pracy socjalnej: czy jako działalności prowadzonej przez państwo, prywatnej praktyki, czy też w ramach sektora non-profit. Chociaż sytuacja w Polsce jest odmienna niż w Stanach Zjednoczonych, to również u nas znajdziemy pracowników socjalnych, którzy prowadzą prywatną praktykę (lecz nie gabinety) lub dla których praca socjalna stała się pasem transmisyjnym do praktyki terapeutycznej czy psychoterapeutycznej. W rozwiniętych krajach świata mamy aktualnie do czynienia z globalnym wzorem trójpodziału pracy socjalnej realizowanej przez państwo, podmioty prywatne i różnego rodzaju zrzeszenia (fundacje, stowarzyszenia, organizacje dobroczynne).

Wokół pracy socjalnej nie jest książką prezentującą jedynie teoretyczne rozważania i abstrakcyjną refleksję na temat problemów, miasta i pracy socjalnej. Autor systematycznie sięga do znaczących opracowań, prezentuje je i konfrontuje ze sobą i ze zmianami społecznymi, jakie zaszły w Stanach Zjednoczonych. Czyni również krótkie spostrzeżenia o tym, jak w naszym kraju wyglądają procesy społeczne i socjalne instytucje. W miarę wyodrębniania się zawodu pracownika socjalnego pojawiły się początkowo takie pojęcia jak ewaluacja, superwizja czy kodeks etyczny w pracy socjalnej. W późniejszym okresie koncepcje i idee zachodniej pracy socjalnej stały się przedmiotem rodzimych opracowań naukowych, studiów porównawczych i doprowadziły do powstania praktyk stosowanych w placówkach pomocowych. 
Uważam, że konsekwentne trzymanie się przez Krzysztofa Frysztackiego amerykańskiego układu odniesienia i upowszechnianie wiedzy na temat amerykańskiej pracy socjalnej i pomocy społecznej w okresie ostatnich trzydziestu lat przyniosło wiele korzyści dla emancypacji profesji i edukacji na poziomie akademickim w Polsce. Te najbardziej ewidentne dotyczą włączenia - przynajmniej części - studentów i pracowników naukowych do wspólnoty międzynarodowej posługującej się tymi samymi pojęciami i koncepcjami oraz komunikującymi się między sobą w podobny sposób.

Należy w tym miejscu dodać, że Frysztacki poza studiowaniem i utrzymywaniem na bieżąco kontaktu z wykładowcami pracy socjalnej na uczelniach amerykańskich, nawiązał i podtrzymywał relacje zawodowe z uczonymi z uniwersytetów włoskich, w tym szczególnie z mediolańskim uniwersytetem katolickim (Università Cattolica del Sacro Cuore), oraz z niemieckich i holenderskich szkół pracy socjalnej.

\section{Kwiaty i owoce}

Każda roślina, czy jest to delikatna orchidea, czy wielotonowy dąb, ma narządy służące do rozmnażania. Naturalnym odpowiednikiem nowych zalążni i ziaren jest kolejne pokolenie badaczy, socjologów i pracowników socjalnych, którzy uzyskują stopnie naukowe. Co więcej, roślina może stworzyć własną niszę w przyrodzie w formie otaczającego ją zespołu roślin lub drzew, na przykład brzozowy zagajnik czy bukowy las. Odpowiednikiem takiej niszy był Zakład Socjologii Stosowanej i Pracy Socjalnej, którym Krzysztof Frysztacki kierował przez kilkadziesiąt lat. Nowe pokolenie badaczy to osoby, które uzyskały doktoraty pod jego kierunkiem, lecz jest ich zbyt dużo by wymienić wszystkich w tym miejscu. Wśród osób natomiast, które uzyskały habilitację, należy wymienić Huberta Kaszyńskiego, Katarzynę Ornacką, Marcjannę Nóżkę, Martę Smagacz-Poziemską oraz autora niniejszego tekstu. Byli oni również współautorami lub współwydawcami rozdziałów i artykułów napisanych wspólnie z Krzysztofem Frysztackim. Aktualnie kontynuują oni pracę w dwóch głównych obszarach badawczych założyciela „Zeszytów Pracy Socjalnej”, czyli socjologii miasta i pracy socjalnej. Co więcej, ich działalność jest instytucjonalnie uformowana w specjalizację społeczeństwa miejskiego na magisterskich studiach socjologicznych i kierunek: praca socjalna (również na poziomie magisterskim). Jego uczniowie podejmują nowe tematy i prowadzą badania w nowych obszarach (takich jak socjologia dzieciństwa, mapy poznawcze ludzi bezdomnych, socjologia historyczna, studia nad pamięcią zbiorową czy zmiany w przestrzeni miasta). Więź z twórczością mistrza jest jednak dostrzegalna w większości ich artykułów, raportów i monografii.

\section{Zakończenie}

Na koniec chciałbym podkreślić, że przedmiotem mojego artykułu jest twórczość pisarska Krzysztofa Frysztackiego, która stanowi tylko fragment jego działalności na 
uniwersytecie. Przed trzy kadencje był dyrektorem i przewodniczącym Rady Naukowej Instytutu Socjologii Uniwersytetu Jagiellońskiego, wieloletnim dyrektorem Instytutu Socjologii Uniwersytetu Opolskiego oraz przewodniczącym Komitetu Socjologii Polskiej Akademii Nauk przez dwie kadencje. Uważam, że w swojej działalności organizacyjnej również wykazywał się kreatywnością. Najlepszymi tego przykładami są stworzenie „Zeszytów Pracy Socjalnej”, które początkowo były wydawane przez Instytut Socjologii UJ, i opieka nad nimi, a także zainicjowanie i kierowanie wymianą studencką i naukową pomiędzy Wydziałem Pracy Socjalnej Ohio State University w Columbus (Ohio) a Instytutem Socjologii. Niemniej jednak te obszary jego aktywności celowo pominąłem, żeby skupić się wyłącznie na jego dorobku piśmienniczym.

Pięćdziesiąt lat z życia człowieka to stosunkowo niewiele w porównaniu z długowiecznością drzew. Pół wieku twórczej pracy na uniwersytecie jest jednak czymś godnym uwagi i upamiętnienia. Zastosowana przeze mnie metafora w dużym przybliżeniu oddaje kreatywność i konsekwencję pracy pisarskiej Krzysztofa Frysztackiego. Pominąłem wiele książek i artykułów z lat 90. XX wieku i pierwszej dekady XXI wieku, a skupiłem się jedynie na ostatnich publikacjach. W nawiązaniu do współczesnych realiów mam nadzieję, że po etapie „przedsiębiorczego uniwersytetu”, nastawionego na produkcję i zysk, pojawią się także nowe formy szkół wyższych pozwalające na poszukiwanie prawdy, nieskrępowaną twórczość, na organiczny, endogenny rozwój. W tym względzie twórczość Krzysztofa Frysztackiego może być przykładem dla przyszłych pokoleń.

\section{Bibliografia}

Frysztacki K. (1982). Organizacja życia społecznego w zbiorowości wielkomiejskiej (studium wybranych grup mieszkańców Krakowa). Zakład Narodowy im. Ossolińskich, Wrocław.

Frysztacki K. (1986). Polonia $w$ dużym mieście amerykańskim. Studium przemian podspołeczności polonijnej w Buffalo. Zakład Narodowy im. Ossolińskich, Wrocław.

Frysztacki K. (2008). Socjalna Ameryka. O obszarze pomocy społecznej i pracy socjalnej w Stanach Zjednoczonych. Zakład Wydawniczy „Nomos”, Kraków.

Frysztacki K. (2009). Socjologia problemów społecznych. Wydawnictwo Naukowe Scholar, Warszawa.

Frysztacki K. (2019). Wokót pracy socjalnej. Od koncepcji i teorii do kontekstów empiryczno-aplikacyjnych. Wydawnictwo Uniwersytetu Jagiellońskiego, Kraków.

Frysztacki K. (red.) (2019). Praca socjalna. 30 wykładów. PWN, Warszawa.

Johnson H.W. (1995). The Social Services: An Introduction. F.E. Peacock Publishers, Itasca.

Radwan-Pragłowski J., Frysztacki K. (1996). Społeczne dzieje pomocy człowiekowi. Od filantropii greckiej do pracy socjalnej. Interart, Warszawa.

Radwan-Pragłowski J., Frysztacki K. (2009). Miłosierdzie i praktyka. Społeczne dzieje pomocy człowiekowi. Wydawnictwo Naukowe „Śląsk”, Katowice. 